\title{
Laajasti lajeista
}

Kaarina Koski, Frog ja Ulla Savolainen (eds.). 2016. Genre - Text Interpretation: Multidisciplinary Perspectives on Folklore and Beyond. Helsinki: Finnish Literature Society. http://dx.doi.org/10.21435/sff.22.

Karina Lukin

$\mathrm{K}$ aarina Kosken, Frogin ja Ulla Savolaisen toimittama lajin käsitettä ruotiva artikkelikokoelma kattaa temaattisesti laajan ja metodologisesti sofistikoituneen pöydän, jossa voi nauttia sekä teoreettisista oivalluksista että kulttuurisesti vaihtelevista näkökulmista genreen. Kirjan taustalla on vuonna 2010 Helsingin yliopistossa järjestetty seminaari "Laji nykytutkimuksessa", ja kirjoittajat ovat valikoituneet paitsi seminaarin esiintyjien, myös yleisen artikkelikutsun perusteella. Toimittamisprosessi on siis ollut kiistämättä pitkä, ja kirjoittajakunnasta on tullut laaja, mutta tulos on niin ikään loistava. Kirjaa voi lukea rinnan kielitieteilijöiden vuonna 2012 julkaiseman monitieteisen Genreanalyysi-mammutin kanssa. Siinä julkaistu Outi Lehtipuron artikkeli saa tarpeellista ja hyvin perusteltua päivitystä Kosken, Frogin ja Savolaisen toimittamassa kokoelmassa.

Genre - Text - Interpretation alkaa historiallisella johdannolla genrekeskusteluihin, mitä seuraa teoreettispainotteiset genren, lajin ja tyypin luonnetta ja uusia mahdollisuuksia avaavat artikkelit. Historiallinen katsaus perustuu ajatukseen aiemmista tekstikeskeisistä genreteorioista, jotka muuntuivat 1960- ja 70-lukujen laajoissa tieteellisissä murroksissa. Katsaus historiaan on tiivis, mutta ehdottoman tarpeellinen ja informatiivinen. Sen avulla on helppo pohtia kokoelman artikkelien suhdetta tutkimushistoriaan ja huomata, että tutkimuksen keskiö on todellakin siirtynyt tekstipainotteisista näkökulmista kohti käytänteiden ja toiminnan tutkimusta. Mutta, kuten historiallisessa johdannossakin todetaan, tekstipainotteisten näkökulmien ei tarvitse olla uudempien tulkintakehysten kanssa vastakohtaisia. Ne täydentävät toisiaan, kunhan tutkija malttaa pohtia yhteensovittamisen mahdollisuuksia.

Kokoelman artikkelit on jaoteltu viiden eri otsikon alle, mikä helpottaa laajan tekstimassan hahmottamista. Tästäkin huolimatta etenen kirja-arviossa toisin: tuon esiin joitakin kirjan perusteella hahmottuvia genrekeskustelujen linjoja.

\section{Bahtinin mahdollisuudet}

Genre - Text - Interpretation -kirjan artikkeleissa usein toistuva nimi on Mihail Bahtin, venäläinen kirjallisuudentutkija, jonka romaanin dialogisuutta käsittelevät tekstit ovat olleet 
suosittuja monilla tekstintutkimuksen alalla. Bahtinin teorioita on 1900- ja 2000-lukujen vaihteesta alkaen sovellettu kirjallisuuden ulkopuolelle, ja erityisesti Charles Briggsin ja Richard Baumanin genreartikkeli (1992) on ollut merkittävä folkloristeille. Ilahduttavasti kirjassa sovelletaan Bahtinin teoriaa myös muun muassa irlantilaisiin juhlakulkueisiin, kuten Ray Cashman tekee. Hänen mukaansa pohjoisirlantilaisten kristillisten ryhmien heinäkuun kahdennentoista paraatiperinne on monologinen, kun taas ceilien, ilta- ja yöaikaan ajoittuvien tapaamisten, aikana kerrotut tarinat tuovat esiin yhteisöllistä dialogisuutta. Vaikka Cashman mielestäni soveltaa bahtinilaista monologin ja dialogin suhdetta hieman yksioikoisesti, hän onnistuu silti tuomaan oivaltavasti esiin, miten eri genrejä käytetään hyväksi ideologian vahvistamisessa tai sen kiistämisessä.

Dialogisuuden lisäksi kokoelman artikkeleissa käytetään Bahtinin perusjakoa yksinkertaisiin ja monimutkaisiin genreihin. Muun muassa muistelukirjoituksia pohtivan Ulla Savolaisen tapa käsitteellistää kirjoituskilpailujen vastauksia monimutkaisina genreinä on suorastaan uraauurtava. Savolaisen mukaan muistelukirjoituksia luonnehtii useiden yksinkertaisten lajien käyttäminen ja dialogisuus, minkä vuoksi ne ovat suhteessa muihin historiallisen ja omaelämäkerrallisen ilmaisun muotoihin. Savolaisen analyysi tuo esiin todenmukaisuuteen viittaamisen keinoja samoin kuin fiktionaalisuuden luomisen tapoja. Lisäksi artikkeli tuo tehokkaasti esiin genren monitahoisuuden ja valottaa oivaltavasti myös vastaanoton merkitystä lajin määrittelyssä.

Bahtinia hyödyntää niin ikään Camilla Asplund Ingemarkin artikkeli, joka analysoi Astrid Lindgrenin novelleja ja keskittyy kronotoopin eli teoksen tila- ja aikaulottuvuuden ja genren suhteeseen. Artikkelinsa lopussa Asplund Ingemark ehdottaa kronotooppia, joka paikantuu genrejen välille, eikä siten aina määrittelisi genreä. Valitettavasti - tai kiehtovasti - kiinnostava ajatus jää leijumaan ilmaan.

\section{Kuilujen yli}

Kuten todettua, Bahtin toistuu muuallakin artikkelikokoelman teksteissä, mikä heijastanee bahtinilaisten ajatusten keskeisyyttä niiden tutkijoiden keskuudessa, jotka pohtivat muodon, sisällön ja lajin välisiä yhteyksiä. Bahtinilaisen teoretisoinnin äänet kaikuvat esimerkiksi artikkelikokoelman alkupuolella teksteissä, jotka koettavat ylittää alan metodologiaan syntyneitä kuiluja äärettömän hienolla tavalla. Tämä lukija piti eniten juuri näistä, Frogin ja Kaarina Kosken artikkeleista, joista molemmat onnistuvat erinomaisella tavalla sekä luomaan katsauksen alan keskusteluihin että kehittämään uusia näkökulmia. Kirjoittajat ovat ylittämässä vierekkäisiä kuiluja, ja molemmat loikkivat taiten.

Frogin lähtökohtana ja innoittajana on genreteorioiden epäyhtenäisyys. Hän lähtee punomaan teoreettista mallia, joka sisältää tekstikeskeisiä näkökulmia mutta painottaa genren toiminnallisia ja kommunikatiivisia funktioita. Monitahoinen ja yksityiskohtaisesti rakennettu kokonaisuus on tarkoitettu joustavaksi: se ei pyri ylikulttuurisiin määrittelyihin, vaan analyyttiseen malliin, jonka avulla tutkijat voivat hahmottaa, kuvata ja eritellä ilmaisun lajeja aineistoissaan.

Teoreettisesti avartava on myös Kaarina Kosken tarinan käsitettä pohtiva artikkeli, jossa Koski keskittyy rekisterin käsitteen avaamiseen ja hyödyntämiseen. Teksti on oiva johdatus tarinantutkimuksen historiaan, ja se avaa hienosti myös folkloristiikan ja tarinankerronnan 
monitahoista nykyisyyttä. Koski hahmottaa tarinantutkimuksessa kolme kuilua: vanhan ja uuden materiaalin välisen, arkistoidun aineiston ja elävän kerronnan välisen sekä toistuvien motiivien havaitsemisen ja puhelajien ja käytänteiden välisen kuilun. Artikkelissa seurataan tutkimushistorian jälkiä, jotka johtavat laajenevalle kentälle. Täällä ei tyydytä enää muotojen ja sisältöjen eikä edes kerronnan tutkimukseen, vaan tarkastellaan kaikkea sitä toimintaa, jota tarinaan liittyen tapahtuu. Prototyyppikategorian avulla tutkija pystyy hallitsemaan vaikeasti järjestettävissä olevaa, hurjasti varioivaa ja usein vaillinaisesti esiin tulevaa mutta silti tunnistetavissa olevaa aineistoa. Hyvä arkistoaineisto auttaa tutkijaa tunnistamaan prototyyppejä niin menneisyydessä kuin nykyisyydessäkin, minkä vuoksi arkisto on oikeastaan välttämätön apuväline kerronnan varioinnin viidakossa.

Kosken prototyyppi rinnastuu Frogin ehdottamaan metonyymiseen genreen, joka taas viittaa tietyn sisällön esittämiseen tavalla, josta puuttuu sen tyypilliset muodot. Vaikka Koski ja Frog kirjoittavat hieman eri asioista, heidän yhteinen huomionsa epätyypillisten, vaillinaisten ja toisiinsa kietoutuvien esitysten merkityksestä on lajin tutkimuksessa tärkeä. Vastaavat havainnot toistuvat artikkelikokoelman muissakin teksteissä, etenkin puhegenren määritelmistä liikkeelle lähtevissä artikkeleissa.

\section{Kulttuurit ylittävät ja kulttuurille erityiset määrittelyt}

Kolmas itseäni artikkelikokoelmassa kiehtova kokonaisuus oli eri lajien määrittelemiseen liittyvän kysymyksenasettelun jatkuvuus. Jo Koski toteaa artikkelinsa alussa, että tarinan genre on ollut tutkijoille hankala tapaus määriteltäväksi: käytännössä yhteisesti tai laajasti hyväksytty määritelmä uupuu tai on vähintäänkin kiistanalainen. Vastaavalla tavalla Genre - Text - Interpretation -kirjassa todetaan myös ainakin huumorista, huhuista ja sananlaskuista.

Kirjoittajat asemoituvat hyvin eri tavoin määrittelemisen suhteen. Yhtenäisen määritelmän tarvetta perustellaan lähinnä vertailulla ja aineiston rajaamisella ja jäsentelyllä, ja kun tutkimuskohde määrittyy yksittäisen genren ja sen variaatioiden vertailun pohjalle, määritelmästä tulee ongelma. Määritelmää pidetään toisin sanottuna tutkimuksen validiteetin kulmakivenä. Tutkimuksen näkökulman siirryttyä ihmisten käytänteitä ja toimintaa kohtaan on alettu enenevissä määrin tarkastella ihmisten omia määritelmiä. Lisäksi pohditaan niin ikään sitä, miten nämä määritelmät tulevat esiin kielellisissä käytänteissä. Toisaalta voidaan tutkia myös, miten määritelmiä käytetään hyväksi, esimerkiksi sitä, millaisia asioita ihmiset tekevät lajeilla ja niitä synnyttävillä poetiikan keinoilla.

Kun artikkelikokoelman tekstejä jaottelee laareihin sen mukaan, etsitäänkö niissä yhtenäistä määritelmää tai ihmisten määritelmää luovia käytänteitä, voi sieltä hahmottaa useita artikkelipareja, joista yksi keskittyy määritelmään ja toinen toimintaan. On ilahduttavaa, että kaikki ovat mahtuneet samojen kansien väliin, eivätkä toimittajat ole lähtökohtaisesti rajanneet näkökulmia.

Samaa kysymyksenasettelua käsittelevät Tomi Kokkonen ja Inkeri Koskinen artikkelissaan, joka jaottelee genrekäsitteet todellisiin tyyppeihin ja heijastumiin (real kinds, projections). Tyypit koostuvat monia yhtenäisiä piirteitä sisältävistä yksiköistä, joiden välisten vertailujen tekeminen on episteemisesti oikeutettua. Heijastumat taas ovat tutkijoiden muodostamia käsitteitä, jotka eivät aina ole yhteneväisiä tyyppien kanssa. Kokkonen ja Koskinen korostavat, että erilaiset genrekäsitykset eivät ole oikeita tai vääriä, mutta niiden hyödyllisyys 
riippuu asetetusta tutkimuskysymyksestä. Ilahduttavasti artikkelikokoelman viimeisien joukossa oleva, Greg Dalzielin artikkeli liikkuu samoilla vesillä, vaikkakin ainoastaan huhun kontekstissa. Dalzielin teksti on mainio esitys huhun tutkimuksen mahdollisuuksista tiedon arvottamisen näkökulmasta, mutta sen historiallinen katsaus tuo niin ikään mainiosti esiin, miten erilaiset määritelmät ovat ennemminkin heijastaneet aikakauden keskusteluja kuin huhujen käytänteitä sinänsä.

\section{Kirjallisuus}

Briggs, Charles ja Richard Bauman. 1992. "Genre, Intertextuality, and Social Power." Journal of Linguistic Anthropology 2(2): 131-172. https://doi.org/10.1525/jlin.1992.2.2.131.

Heikkinen, Vesa, Heikki Voutilainen, Petri Lauerma, Ulla Tiiliä ja Mikko Lounela (toim.). 2012. Genreanalyysi: tekstilajitutkimuksen käsikirja. Helsinki: Gaudeamus.

FT Karina Lukin on folkloristiikan tutkija Helsingin yliopistossa. 